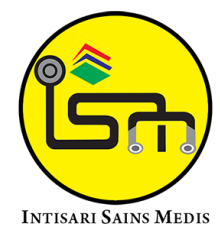

Published by Intisari Sains Medis

\title{
Pruritus dan modalitas terapi terkini: Sebuah tinjauan pustaka
}

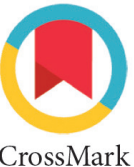

CrossMark

\author{
Odilia Dea Novena ${ }^{1 *}$, Ni Gusti Putu Raka Ariani ${ }^{1}$
}

\section{ABSTRACT}

Pruritus or itching is an unpleasant feeling that causes the urge to scratch, the most common symptom found in skin diseases. Histamine and several other mediators such as opioid peptides and 5-hydroxytryptamine (5-HT) also influence the occurrence of pruritus. The prevalence of pruritus in the general population varies from $8 \%$ to $38 \%$ worldwide. Pruritus is categorized into 4 types, neuropathic, psychogenic, neurogenic, and pruriroceptive pruritus. When physically examining the skin, primary skin lesions must be distinguished from secondary lesions due to chronic scratching. Dermatological signs of chronic scratching include excoriation, lichenification, prurigo nodularis or a combination of these. Management of pruritus depends on the underlying etiology. Therapy should be focused on the underlying etiology. There are pharmacological and non-pharmacological therapies, where non-pharmacological therapies focus on avoiding precipitating factors and phototherapy. Pharmacological therapy can be in the form of topical and oral therapy. Some examples of topical therapies used in daily practice are emollients, corticosteroids,

Keywords: pruritus, systemic, topical, treatment.

Cite This Article: Novena, O.D., Ariani, N.G.P.R. 2021. Pruritus dan modalitas terapi terkini: Sebuah tinjauan pustaka. Intisari Sains Medis 12(3): 694-698. D0l: 10.15562/ism.v12i3.1128

\section{ABSTRAK}

Pruritus atau rasa gatal adalah perasaan tidak menyenangkan yang menyebabkan keinginan untuk menggaruk merupakan gejala yang paling umum ditemukan pada penyakit kulit. Histamin dan beberapa mediator lainnya seperti peptida opiod dan 5-hidroksitriptamin (5-HT) juga memengaruhi terjadinya pruritus. Prevalensi pruritus pada populasi umum bervariasi mulai dari $8 \%$ sampai dengan $38 \%$ di seluruh dunia. Pruritus dikategorikan menjadi 4 tipe, yaitu pruritus neuropatik, psikogenik, neurogenik, dan pruriroseptif. Saat memeriksa kulit secara fisik, lesi kulit primer harus dibedakan dari lesi sekunder akibat garukan kronis. Tanda-tanda dermatologis dari garukan kronis termasuk ekskoriasi, likenifikasi, immunomodulators, capsaicin, antihistamines and topical anesthetics. Oral drugs that are currently the main choice for treating pruritus are antihistamines, but there are several other options being considered, namely anticonvulsants, opioid modulators, and antidepressants. A comprehensive history and physical examination are needed to determine the triggering factors for the onset of pruritus. The management of pruritus depends on the underlying etiology and the success of therapy is also influenced by the patient's adherence to treatment. Treatment of pruritus can be in the form of non-pharmacological therapy and pharmacological therapy. Pharmacological therapy can be both topical and systemic. Commonly used topical therapies are emollients, corticosteroids and topical anesthetics. Antihistamines remain the mainstay of systemic therapy used for pruritus. The purpose of writing this article is to discuss more deeply about the treatment modalities of pruritus which are summarized from various journals and research in order to provide consideration when choosing the right therapy in daily practice.
'Dokter Magang Rumah Sakit Umum Bangli, Bangli, Bali, Indonesia;

\footnotetext{
*Korespondensi:

Odilia Dea Novena;

Dokter Magang Rumah Sakit Umum Bangli, Bangli, Bali, Indonesia;

odiliadeanovenaa@gmail.com
}

Diterima: 31-08-2021

Disetujui: 02-10-2021

Diterbitkan: 26-10-2021 prurigo nodularis atau kombinasi dari semuanya. Penatalaksanaan pruritus bergantung pada etiologi yang mendasari. Terapi yang diberikan harus difokuskan pada etiologi yang mendasari. Terdapat terapi farmakologi dan non-farmakologi, dimana terapi non farmakologi fokus terhadap menghindari faktor pencetus serta fototerapi. Terapi farmakologi dapat berupa terapi topikal dan oral. Beberapa contoh terapi topikal yang digunakan dalam praktik seharihari adalah emolien, kortikosteroid, imunomodulator, capsaisin, antihistamin dan anestesi topikal. Obat oral yang hingga saat ini menjadi pilihan utama terapi pruritus adalah antihistamin, namun terdapat beberapa pilihan lain yang dipertimbangkan yaitu 
antikonvulsan, modulator opioid, antidepresan. Anamnesis dan pemeriksaan fisik yang komprehensif sangat diperlukan untuk mengetahui faktor pencetus timbulnya pruritus. Penatalaksanaan pruritus bergantung pada etiologi yang mendasari dan keberhasilan terapi juga dipengaruhi oleh ketaatan pasien dalam berobat. Terapi pruritus dapat berupa terapi non-farmakologis dan terapi farmakologis. Terapi farmakologis dapat berupa topikal dan sistemik.

Kata kunci: pruritus, sistemik, terapi, topikal.

Sitasi Artikel ini: Novena, 0.D., Ariani, N.G.P.R. 2021. Pruritus dan modalitas terapi terkini: Sebuah tinjauan pustaka. Intisari Sains Medis 12(3): 694-698. D0I: 10.15562/ism.v12i3.1128

\section{PENDAHULUAN}

Pruritus atau rasa gatal adalah perasaan tidak menyenangkan yang menyebabkan keinginan untuk menggaruk, yang secara negatif memengaruhi aspek psikologis dan fisik dari kehidupan seseorang. Pruritus merupakan gejala yang paling umum ditemukan pada penyakit kulit, yang dapat bersifat ringan hingga tidak dapat ditoleransi. Rasa gatal yang muncul dapat bersifat terus menerus atau hilang timbul, serta bersifat lokal atau umum. Rasa gatal terkait dengan teleneuron bebas yang didistribusikan di lapisan superfisial dari epidermis. Secara fisiologis, rasa gatal muncul dari sensasi kulit secara sadar yang menimbulkan refleks untuk menggaruk. Tujuan dari refleks ini adalah untuk menghilangkan rangsangan tersebut. Namun, menggaruk dapat menyebabkan kerusakan lebih lanjut pada kulit dan dapat memperburuk masalah. Pruritus pada dasarnya dapat dihilangkan dengan trauma yang menggantikan rasa gatal dengan rasa sakit, akan tetapi tindakan tersebut dapat mengakibatkan perubahan kronis pada kulit, seperti likenifikasi, eritema, ekskoriasi, dan bahkan laserasi. Mekanisme terjadinya pruritus belum dapat sepenuhnya dijelaskan. Histamin telah dijelaskan sebagai salah satu mediator terjadinya pruritus dan beberapa studi terakhir menunjukkan bahwa terdapat beberapa mediator lainnya seperti peptida opiod dan 5-hidroksitriptamin (5-HT) yang juga memengaruhi terjadinya pruritus. ${ }^{1}$

Pruritus dapat muncul karena adanya penyakit kulit maupun penyakit sistemik. Beberapa penyakit kulit yang dapat menimbulkan pruritus antara lain xerosis (atau kulit kering), dermatitis atopik, dermatitis kontak alergi, dan infeksi parasit atau kutu, sedangkan penyakit sistemik yang dapat menimbulkan pruritus antara lain gangguan ginjal dan hati dengan maupun tidak dengan kolestasis, infeksi seperti HIV dan hepatitis $\mathrm{C}$, penyakit hematologi seperti defisiensi besi dan polistemia vera, gangguan endokrin seperti penyakit tiroid dan diabetes mellitus, dan penyakit paraneoplastik seperti limfoma dan tumor organ padat. Terapi untuk pruritus terdiri dari tatalaksana penyakit yang mendasari, intervensi nonfarmakologis seperti pemberian pelembab, menghindari iritan, mengurangi stres, dan menghentikan garukan pada kulit, terapi farmakologis lokal seperti pemberian kortikosteroid atau penghambat kalsineurin topikal, terapi farmakologis sistemik seperti pemberian antihistamin oral, serta fototerapi. ${ }^{1-3}$

\section{EPIDEMIOLOGI}

Pruritus dapat ditemui pada berbagai macam jenis penyakit kulit. Prevalensi pruritus pada populasi umum bervariasi mulai dari $8 \%$ sampai dengan 38\% di seluruh dunia. Penelitian yang dilakukan pada 25.441 orang di Perancis menunjukkan prevalensi pruritus kronis sebanyak $14,4 \%$ dalam jangka waktu 2 tahun. ${ }^{4}$ Sebuah studi di Cina menunjukkan bahwa prevalensi dan intensitas pruritus ditemukan lebih tinggi pada pasien dengan dermatitis eksim atau urtikaria dibandingkan dengan penyakit kulit lainnya. ${ }^{5}$ Studi lain yang dilakukan di Amerika Serikat selama 11 tahun menunjukkan bahwa terdapat 11 juta kunjungan untuk keluhan gatal dengan rerata 7 juta kunjungan setiap tahunnya. Keluhan gatal ini muncul kurang lebih pada $1 \%$ dari keseluruhan kunjungan ke dokter. ${ }^{6}$ Penelitian terkini oleh Carr dkk. yang menggunakan survei melalui telepon pada 1.075 veteran militer Amerika Serikat menunjukan prevalensi pruritus kronis sebanyak kurang lebih 38\%.7 Prevalensi dan intensitas pruritus yang lebih berat telah diketahui meningkat seiring bertambahnya usia. ${ }^{5}$

\section{ETIOPATOGENESIS}

Pruritus dikategorikan menjadi 4 tipe, yaitu pruritus neuropatik, psikogenik, neurogenik, dan pruriroseptif. Pruritus neuropatik disebabkan oleh adanya kerusakan pada neuron sensorik sentral atau perifer yang menyebabkan rangsangan pada neuron pruritus tanpa adanya rangsangan pada kulit yang bersifat pruritogenik. Rasa gatal tipe ini dapat disebabkan oleh lesi primer atau disfungsi pada titik tertentu sepanjang jalur aferen dari sistem saraf. Oleh karena lokasi kerusakan saraf yang sesungguhnya jauh dari lokasi gatal yang sebenarnya, menggaruk rasa gatal neuropatik tidak efektif. Pruritus neuropatik juga sering diikuti dengan gangguan sensorik lainnya seperti parestesi, hiperestesi, atau hipoestesi. ${ }^{8}$

Pruritus psikogenik dihubungkan dengan gangguan psikologis. Rasa gatal ini biasanya muncul dengan rangsangan berlebihan untuk menggaruk kulit yang sebenarnya normal. Pruritus psikogenik 
melibatkan gangguan otak atau psikiatrik yang belum dapat didefinisikan dengan jelas, akan tetapi diagnosis psikiatrik seperti depresi, gangguan obsesif kompulsif, cemas, gangguan somatoform, mania, psikosis, dan penyalahgunaan obat telah dihubungkan dengan manifestasi fisik berupa rasa gatal. Mekanisme atau patofisiologi pruritus psikogenik juga masih belum dapat dijelaskan sepenuhnya. Pruritus neurogenik dan sistemik muncul dari gangguan yang terjadi pada sistem organ di luar kulit. Beberapa penyakit yang dapat menyebabkan hal ini antara lain gagal ginjal kronik, penyakit hati, hematologi, kondisi limfoproliferatif, dan keganasan. Rasa gatal ini ditransmisikan melalui sistem saraf pusat, akan tetapi belum ada bukti nyata mengenai mekanisme patologis saraf yang dapat ditemukan. Pruritus pruritoseptif adalah tipe yang paling umum ditemukan oleh dokter kulit. Rasa gatal dihasilkan di kulit melalui inflamasi atau kerusakan pada kulit, dan umumnya dapat terlihat melalui pemeriksaan klinis. Perubahan struktur pelindung kulit yang terkait dengan usia juga dapat menimbulkan pruritus pruritoseptif. Tipe pruritus ini ditemukan pada sebagian besar kasus pruritus klinis karena semua faktor baik mediator endogen maupun alergen eksogen yang berkontak dengan kulit dapat menginduksi terjadinya rasa gatal pruritoseptif., ${ }^{90}$

Mekanisme dan jalur neurologis yang mungkin mendasari manifestasi pruritus dimulai dari stimulus gatal yang merangsang sel-sel, seperti sel imun dan keratinosit di kulit untuk mengeluarkan mediator rasa gatal. Termasuk di dalamnya adalah mediator inflamasi, neuromediator, dan neuropeptida. Mediator ini berikatan dengan reseptor mediator-mediator tersebut dan mengaktivasi saraf sensorik yang spesifik. Sinyal gatal diteruskan dari jalur sinyal mechanically-insensitive C-fibers (CMi) atau mechanically-sensitive C-type fibers (CMHs) ke dorsal root ganglion (DRG) dari medula spinalis, menyeberangi traktus spinotalamik ke thalamus, dan pada akhirnya ke korteks somatosensorik. Kemudian, otak mengartikan sinyal ini sebagai sensasi gatal. ${ }^{1,11}$

\section{MANIFESTASI KLINIS}

Langkah pertama dalam mengevaluasi pasien dengan pruritus harus melibatkan anamnesis riwayat menyeluruh dan pemeriksaan fisik pada kulit. Riwayat komprehensif yang terdiri dari riwayat medis, keluarga, dan obat-obatan di masa lalu, serta tinjauan sistem secara menyeluruh, dapat membantu memberikan arahan lebih lanjut untuk diagnosis yang mendasari. Misalnya, gejala konstitusional mungkin menunjukkan keganasan yang mendasari dan berkontribusi terhadap pruritus. ${ }^{12}$

Pasien dengan riwayat hipertensi harus ditanyakan mengenai penggunaan penghambat saluran kalsium atau penghambat angiotensin-converting enzyme (ACE), obat yang umumnya diketahui menyebabkan pruritus tanpa ruam. Obat lain yang secara umum diketahui dapat menyebabkan pruritus tanpa ruam yang diinduksi obat termasuk mu-opioid. Pertanyaan mengenai lokasi pruritus juga sangat penting. Misalnya, pruritus neuropatik cenderung bermanifestasi sebagai pruritus lokal (seringkali di sepanjang dermatom), sedangkan pruritus yang diinduksi obat lebih mungkin muncul sebagai pruritus umum. ${ }^{13,14}$

Saat memeriksa kulit secara fisik, lesi kulit primer harus dibedakan dari lesi sekunder akibat garukan kronis. Garukan kronis dapat menyebabkan beberapa macam lesi yang nonspesifik. Tanda-tanda dermatologis dari garukan kronis termasuk ekskoriasi (yaitu, bekas garukan), likenifikasi (yaitu, area kulit yang menebal akibat gosokan berulang), prurigo nodularis (yaitu, lesi nodular) atau kombinasi dari semuanya. Selain itu, pasien dengan keluhan gatal kronis sering kali datang dengan butterfly sign, suatu area hipopigmentasi yang sering terlihat di area punggung yang tidak terjangkau. Hal ini dapat membantu mengarahkan diagnosis banding ke penyebab dermatologis atau nondermatologis. ${ }^{14}$

Penyebab utama lesi terkadang sulit diketahui. Jika pruritus terlokalisir, lesi primer kulit dapat mengarah ke diagnosis tertentu. ${ }^{2}$ Bila muncul dalam distribusi dermatomal yang diikuti dengan rasa nyeri, terbakar, atau kehilangan sensasi, dapat dipikirkan sebuah patogenesis neuropatik seperti neuralgia paskaherpetik. Mekanisme pruritus pada penyakit ini berhubungan dengan kerusakkan sistem saraf. ${ }^{1,2}$ Penyebab dermatologi lainnya yang dapat menyebabkan pruritus adalah xerosis, skabies, dermatitis kontak, infeksi jamur, gigitan serangga, pedikulosis, urtikaria, pitiriasis rosea, dan lain-lain. ${ }^{11}$

Selain itu, pruritus juga dapat ditemukan pada penyakit dermatosis autoimun dan inflamasi. Pruritus dapat ditemui pada dermatitis atopik yang umumnya ditunjukan dengan adanya siklus gatal-garuk yang jelas. Psoriasis awalnya dianggap sebagai dermatosis non-pruritik, akan tetapi $60-90 \%$ dengan psoriasis mengalami pruritus. Rasa gatal ini memberat pada pasien dengan kulit kering, stres, atau disertai dengan depresi dan gangguan cemas. ${ }^{1,15}$ Pruritus juga dapat ditemukan pada penyakit autoimun bulosa, bulosa pemfigoid, dan dermatitis herpetiformis (guhring's disease). Penyakit jaringan ikat seperti sklerosis sistemik, morfea, lupus, sindroma sjorgen, dermatomiositis, dan vitiligo juga dapat menimbulkan keluhan pruritus pada penderitanya. $^{15}$

Diagnosis banding untuk pruritus umum tanpa lesi primer membutuhkan pemeriksaan yang lebih lengkap. Diagnosis xerosis perlu disingkirkan terlebih dahulu dan pemeriksaan fisik perlu disesuaikan dengan temuan klinis penyakit sistemik yang biasanya dapat ditandai dengan tanda-tanda khas seperti stigmata penyakit hati kronis, konjungtiva pucat, tiromegali, splenomegali, dan limfadenopati. Penyakit sistemik yang mendasari dapat berupa infeksi sampai dengan keganasan. Riwayat menggunakan obat-obatan atau hubungan seksual bebas yang berpotensi menyebabkan infeksi HIV atau hepatitis C. Polidipsia dan poliuria dapat menunjukkan diabetes melitus. Penyakit pada ginjal dapat menyebabkan pruritus uremik dan intoleransi suhu dapat menandakan disfungsi tiroid. Perubahan suasana hati, kekhawatiran yang tidak sesuai, atau adanya pola obsesif dapat menunjukkan penyebab psikiatri., ${ }^{2,16}$ Pemeriksaan laboratorium dan pencitraan juga disarankan untuk memastikan etiologi yang mendasari pruritus. ${ }^{14}$ 


\section{MODALITAS TERAPI TERKINI}

Penatalaksanaan pruritus bergantung pada etiologi yang mendasari. Jika memungkinkan, terapi yang diberikan harus difokuskan pada etiologi yang mendasarinya. Namun, jika keluhan masih belum teratasi, pengobatan simptomatik diperlukan. Tatalaksana non farmakologis yang dapat dilakukan antara lain menggunakan sampo dan sabun yang tidak memiliki deterjen kuat, membilas sabun dan sampo secara menyeluruh untuk menghilangkan residu, menghindari air panas ketika mandi, menghindari alat mandi yang dapat menyebabkan sensasi terbakar, menghindari penggunaan handuk yang kasar atau berbahan nilon, jaga suhu ruang dengan kelembaban yang tepat, potong kuku pendek, dan penggunaan sarung tangan atau perban dapat membantu untuk proteksi. . $^{3,14}$

Emolien atau pelembab topikal adalah zat yang dapat memperbaiki penghalang kulit melalui pengurangan kehilangan air transepidermal [transepidermal water loss (TEWL)] dan pencegahan penetrasi bahan eksogen. Krim pelembab adalah pengobatan andalan untuk gejala pruritus ringan yang terlokalisir, yang mungkin merupakan manifestasi xerosis. Pelembab topikal juga merupakan komponen penting dalam pengobatan dermatitis atopik dan harus digunakan setiap hari untuk terapi pemeliharaan. Pelembab komersial mungkin tersedia dalam bentuk atau formulasi yang berbeda (seperti krim, salep, dan lotion), dan pilihan yang paling tepat untuk setiap pasien tergantung pada preferensi individu, biaya, dan area tubuh. Pasien harus diperingatkan untuk menghindari penggunaan produk yang mengandung lanolin dan wewangian, karena pasien dengan atopi seringkali sensitif terhadap zat ini. Kortikosteroid topikal potensi rendah juga dapat ditambahkan ke formulasi emolien pada pasien dengan eksim berat sebagai terapi wet-wrap pajama. Metode ini meliputi menutupi area tubuh yang terkena dengan krim kortikosteroid-emolien, mengenakan piyama basah, mengenakan piyama kering di atas piyama basah, dan dibiarkan semalaman. Perawatan ini harus digunakan hanya sekali setiap minggu karena risiko terkait penyerapan steroid topikal dan folikulitis. Selain itu, dokter harus merekomendasikan emolien dan pembersih dengan $\mathrm{pH}$ rendah $(4,5-6,0)$ kepada pasien dengan pruritus. Hal ini dikarenakan zat dengan $\mathrm{pH}$ tinggi dapat mengaktifkan protease serin di kulit, yang menyebarkan sensasi pruritus. Oleh karena itu, sabun batangan dan pembersih yang memiliki $\mathrm{pH}$ sangat tinggi tidak boleh digunakan selama perawatan kulit pasien dengan pruritus. ${ }^{14}$

Kortikosteroid sebagai agen antiinflamasi topikal yang paling efektif sering digunakan untuk menghilangkan pruritus dari penyakit kulit yang disebabkan oleh mediator gatal, tetapi penggunaan kortikosteroid dalam jangka panjang sebaiknya dihindari karena dapat menyebabkan kulit atrofi dan kering, yang terkadang dapat diikuti dengan jerawat, rosasea, dan dermatitis perioral. Oleh karena itu, penggunaan kortikosteroid dalam jangka pendek lebih disarankan. ${ }^{1} \quad$ Beberapa kortikosteroid yang digunakan untuk mengatasi pruritus antara lain hidrokortison, betametason dipropionat, dan klobetasol dipropionat. Pilihan obat topikal lainnya adalah imunosupresan penghambat kalsineurin seperti takrolimus dan pimekrolimus, yang memiliki efektivitas serupa dengan kortikosteroid dalam pengelolaan gatal, tetapi dengan efek samping signifikan yang lebih sedikit. ${ }^{1,17}$

Imunomodulator topikal seperti pimecrolimus berperan dalam aktivasi sel $T$, dan menghambat sitokin proinflamasi serta memperbaiki lapisan kulit. Efek antipruritus dimediasi oleh aktivasi dan desentisasi TRPV1. Pimecrolimus $1 \%$ digunakan dua kali sehari selama 3 minggu terbukti menurunkan TEWL dan memperbaiki lapisan lipid pada stratum korneum. Penggunaaan calcineurin inhibitor harus dimonitor secara ketat pada pasien anak karena terdapat risiko terjadinya leukemia., ${ }^{1,18}$

Capsaisin topikal bekerja dengan menimbulkan influx kalsium yang berefek pada penurunan neuropeptide pruritogenik seperti substansi P. Krim capsaisin digunakan 3-4 kali sehari. Efek samping umum yang mungkin timbul adalah eritema lokal, dan sensasi terbakar sementara. Hal tersebut dapat diatasi dengan anestesi topikal yang diaplikasikan pada beberapa hari pertama. ${ }^{17,18}$
Topikal antihistamin hanya disarankan dalam terapi pruritus yang disebabkan oleh urtikaria dan pruritus yang disebabkan oleh gigitan serangga. Doxepin merupakan salah satu agen antihistamin topikal yang terbukti memiliki efikasi dalam mengurangi gejala pruritus, dapat menimbulkan efek samping seperti dermatitis kontak alergi serta penggunaanya harus berhati-hati pada pasien anak-anak dan lansia. ${ }^{18}$

Anestesi topikal juga dapat berguna untuk mengobati berbagai jenis pruritus lokal. Pramoxine telah terbukti memberikan efek antipruritik pada berbagai penyakit, termasuk psoriasis, pruritus uremik, dan dermatitis atopik. Sediaan obat topikal yang mengandung ketamin, amitriptilin, dan lidokain (KAL) dalam basis liposomal juga telah terbukti mengurangi rasa gatal pada berbagai kondisi pruritus dan dapat digunakan sebagai terapi tunggal atau tambahan yang efektif. Efek samping yang mungkin muncul yaitu rasa terbakar pada area aplikasi dan eritema, yang terkadang dapat menyebabkan ketidakpatuhan pasien. Pilihan lainnya adalah dengan menggunakan agen pendingin, seperti mentol, kamper, dan fenol, yang telah terbukti berhasil dalam mengobati berbagai jenis gatal melalui modulasi saluran termosensitif di kulit. Konsentrasi mentol yang cenderung mengurangi sensasi pruritus berkisar antara $1 \%$ hingga $3 \%$, konsentrasi yang lebih tinggi dapat menyebabkan iritasi kulit. ${ }^{14}$

Pilihan terapi sistemik yang dapat digunakan untuk tatalaksana pruritus antara lain antihistamin, seperti hidroksizin, difenhidramin, dan doksepin; antikonvulsan, seperti gabapentin dan pregabalin; modulator opioid, seperti butorfanol dan naltrekson; serta antidepresan, seperti sertraline, paroksetin, fluvoksamin, dan mirtazapin. ${ }^{3,14}$ Beberapa modalitas terapi yang diteliti sebagai pilihan terapi untuk pruritus kronik adalah opioidergic drugs (mu-opioid antagonists dan kappa-opioid agonists), neurokinin-1 receptor antagonists, biologic drugs, Janus kinase inhibitors, ileal bile acid transporter inhibitors, aryl hydrocarbon receptor agonists, dan histamine $\mathrm{H} 4$ receptor antagonists. ${ }^{19}$ 
Selain itu, fototerapi telah digunakan dalam berbagai penyakit kulit inflamasi. Sinar ultraviolet (UV) dapat secara langsung memengaruhi serabut saraf sensorik atau secara tidak langsung melalui pelepasan mediator dari sel-sel di dalam kulit, memodulasi fungsi serta transmisi gatal ke sistem saraf pusat dan menginduksi efek anti gatal. ${ }^{20} \mathrm{UVB}$ pita sempit (narrow band UVB / NB-UVB) telah terbukti menjadi bentuk fototerapi yang efektif dengan efek eritemogenik yang lebih sedikit dibandingkan dengan UVB pita lebar (broad band UVB / BBUVB) dan potensi karsinogenik yang lebih rendah dibandingkan dengan PUVA. Oleh karena itu, NB-UVB adalah pilihan pertama dalam pengobatan pruritus yang berhubungan dengan dermatitis atopik, psoriasis, urtikaria, limfoma sel $\mathrm{T}$ kulit, dan prurigo. $^{21}$

\section{SIMPULAN}

Pruritus atau rasa gatal adalah perasaan tidak menyenangkan yang menyebabkan keinginan untuk menggaruk, dan merupakan gejala yang paling umum ditemukan pada penyakit kulit. Secara patofisiologi, terjadinya pruritus belum dapat sepenuhnya dijelaskan. Pruritus dikategorikan menjadi 4 tipe, yaitu pruritus neuropatik, psikogenik, neurogenik, dan pruriroseptif. Secara onset, pruritus dapat dibedakan menjadi akut dan kronik, dikatakan kronik jika terjadi lebih dari 6 minggu. Anamnesis dan pemeriksaan fisik yang komprehensif sangat diperlukan untuk mengetahui faktor pencetus timbulnya pruritus. Diagnosis banding untuk pruritus umum tanpa lesi primer membutuhkan pemeriksaan yang lebih lengkap karena adanya keterkaitan dengan penyakit penyerta lain. Penatalaksanaan pruritus bergantung pada etiologi yang mendasari dan keberhasilan terapi juga dipengaruhi oleh ketaatan pasien dalam berobat.

\section{UCAPAN TERIMA KASIH}

Ucapan terima kasih penulis berikan kepada seluruh pihak atas dukungan yang telah diberikan dalam penulisan tinjauan pustaka ini.

\section{KONFLIK KEPENTINGAN}

Penulis menyatakan tidak terdapat konflik kepentingan (conflict of interest) pada penulisan laporan tinjauan pustaka ini.

\section{PENDANAAN}

Penulis bertanggung jawab terhadap seluruh pembiayaan dalam pembuatan laporan tinjauan pustaka ini.

\section{KONTRIBUSI PENULIS}

Seluruh penulis bertanggung jawab dalam pembuatan dan penulisan laporan tinjauan pustaka ini.

\section{DAFTAR PUSTAKA}

1. Song J, Xian D, Yang L, Xiong X, Lai R, Zhong J. Pruritus: Progress toward Pathogenesis and Treatment. Biomed Res Int. 2018; 9625936.

2. Nowak D, Yeung J. Diagnosis and treatment of pruritus. Can Fam Physician. 2017; 63:918-24.

3. Satoh T, Yokozeki H, Murota H, Tokura Y, Kabashima K, Takamori K, et al. 2020 guidelines for the diagnosis and treatment of cutaneous pruritus. J Dermatol. 2021; 130:1589-1606.

4. Ständer S, Weisshaar E, Mettang T, Szepietowski JC, Carstens E, Ikoma A, et al. Clinical Classification of Itch: a Position Paper of the International Forum for the Study of Itch. Acta Derm Venerol. 2007; 87:291-4.

5. Wang X, Lai Q, Ye L, Wen S, Yan Y, Yang B, et al. Both Prevalence and Severity of Pruritus are Associated with Age in Chinese Patients with Skin Diseases. Clin Cosmet Investig Dermatol. 2021; 14:217-23.

6. Shive M, Linos E, Berger T, Wehner M, Chren M-M. Itch as a Patient-Reported Symptom in
Ambulatory Care Visits in the US. J Am Acad Dermatol. 2014; 69:550-6.

7. Carr CW, Veledar E, Chen SC. Factors mediating the impact of chronic pruritus on quality of life. JAMA Dermatology. 2014; 150:613-20.

8. Oaklander AL. Common Neuropathic Itch Syndromes. Acta Derm Venerol. 2012; 92:11825.

9. Greaves MW. Pathogenesis and Treatment of Pruritus. Curr Allergy Asthma Rep. 2010; 10:236-42.

10. Cevikbas F, Lerner EA. Physiology and pathophysiology of itch. Physiol Rev. 2020; 100:945-82.

11. Tivoli YA, Rubenstein RM. Pruritus an Updated Look at an Old Problem. J Clin Arthetic Dermatology. 2009; 2:30-6.

12. Hashimoto $\mathrm{T}$, Yosipovitch G. Itching as a systemic disease. J Allergy Clin Immunol. 2019; 144:375-80.

13. Rosen JD, Fostini AC, Yosipovitch G. Diagnosis and Management of Neuropathic Itch. Dermatol Clin. 2018; 36:213-24.

14. Golpanian RS, Gonzalez JM, Yosipovitch G. Practical Approach for the Diagnosis and Treatment of Chronic Pruritus. J Nurse Pract. 2020; 16:590-6.

15. Zeidler C, Pereira MP, Huet F, Misery L, Steinbrink K, Ständer S. Pruritus in Autoimmune and Inflammatory Dermatoses. Front Immunol. 2019; 10:1-8.

16. Tarikci N, Kocatürk E, Güngör F, Topal IGOL, Can PÜ, Singer R. Pruritus in Systemic Diseases: A Review of Etiological Factors and New Treatment Modalities. Sci World J. 2015; 803752.

17. Harrison IP, Spada F. Breaking the Itch - Scratch Cycle: Topical Options for the Management of Chronic Cutaneous Itch in Atopic Dermatitis. Medicines. 2019;6(3):76.

18. Yosipovitch G, Misery L, Proksch E, Metz M, Ständer S, Schmelz M. Skin Barrier Damage and Itch: Review of Mechanisms, Topical Management and Future Directions. Acta Derm Venereol. 2019;99(13):1201-9.

19. Reszke R, Krajewski P, Szepietowski JC. Emerging Therapeutic Options for Chronic Pruritus. Am J Clin Dermatol. 2020; 21:601-18.

20. Legat FJ. The Antipruritic Effect of Phototherapy. Front Med. 2018; 5:333.

21. Wallengren J. Ultraviolet Phototherapy of Pruritus. In: Misery L, Stander, editors. Pruritus. New York: Springer; 2016. p. 425-36. 